\title{
Determination of shelf life of Gibel Carp (Carassius gibelio, Bloch 1782) marinades in different sauces stored at $4^{\circ} \mathrm{C}$
}

\section{Farklı soslarda $4{ }^{\circ} \mathrm{C}$ 'de depolanan Gümüşi Havuz Balığı (Carassius gibelio, Bloch 1782) marinatlarının raf ömrünün belirlenmesi}

\author{
Latif Taşkaya • Yunus Alparslan* • Hatice Hasanhocaoğlu Yapıcı • Cansu Metin \\ Taçnur Baygar
}

Muğla Sıtkı Koçman University, Fisheries Faculty, Department of Seafood Processing Technology, 48000, Muğla, Turkey *Corresponding author: yunusalparslan@mu.edu.tr

\begin{abstract}
In this study, quality properties and shelf life for gibel carp (Carassius gibelio, Bloch 1782 ) marinades during stored at $4 \pm 1^{\circ} \mathrm{C}$ in different sauces was investigated. The marinating process was carried out in $2.5 \%$ vinegar, $10 \%$ salt and water for $72 \mathrm{~h}$ at $4 \pm 1^{\circ} \mathrm{C}$. After the marination process, fish were removed from the solutions, transferred in to glass jar contain with different sauces (Group A: sunflower oil and tomato paste, Group B: sunflower oil with garlic, red pepper, thyme, basil and mint and the control group: sun flower oil). Sensory, chemical, colour and microbiological analyses were performed during the storage. According the chemical analysis results TVB-N and TBA values of all groups were increased during the storage, but during the stored period did not exceed acceptible limit values. The highest TVB-N and TBA values were group $A$. $(P<0,05)$. At the end of 135 days of storage, sensory analysis results pointed out that the marinades of group $B$ did not exceed acceptible limit values $(P<0,05)$. The overall microbial load of the fresh samples decreased through out the storage period $(P<0,05)$. By sensory data, shelf life of sauced gibel carp marinades were 120 days (control), 105 days (group A) and 135 days (group B).
\end{abstract}

Keywords: Carassius gibelio, Gibel carp, marination; quality properites, shelf life, sauces

Öz: Bu çalışmada, farklı soslarda $4 \pm 1^{\circ} \mathrm{C}$ 'de depolanan gümüşi havuz balığı (Carassius gibelio, Bloch 1782) marinatlarının raf ömürlerinin tespit edilmesi amaçlanmıştır. Marinasyon işlemi \% 2,5 sirke ve \%10 tuz ile $4 \pm 1^{\circ} \mathrm{C}$ 'de 72 saatte gerçekleştirilmiştir. Marinasyon işleminden sonra balıklar solüsyondan çıkarılmış ve farklı soslar içeren (A grubu: ayçiçeği yağı ve domates salçası; B grubu: ayçiçeği yağı, sarımsak, kırmızı pul biber, kekik, fesleğen ve nane; Kontrol grubu: ayçiçeği yağı) cam kavanozlara yerleştirilmiştir. Buzdolabı şartlarında 135 gün depolama boyunca duyusal, kimyasal, renk ölçümü ve mikrobiyolojik analizler gerçekleştirilmiştir. Kimyasal analiz sonuçlarına göre bütün örneklerin TVB-N ve TBA değerleri muhafaza süresince artış göstermiş ancak depolama boyunca kabul edilebilir sınır değerleri içerisinde kaldığı tespit edilmiştir. Depolama sonunda en yüksek TVB-N ve TBA değeri A grubu örneklerde görülmüştür (P<0,05). 135 günlük depolama sonunda $B$ grubu marinatların duyusal değerlendirme açısından tüketilebilir limit değerleri içerisinde kaldığı tespit edilmiştir ( $P<0,05)$. Taze örneklerdeki toplam mikrobiyolojik yükün depolama boyunca azaldığı gözlemlenmiştir $(P<0,05)$. Duyusal analiz sonuçlarına göre Kontrol, $A$ ve $B$ grubu örneklerin raf ömrü sırasıyla 120, 105 ve 135 gün olarak tespit edilmiştir.

Anahtar kelimeler: Carassius gibelio, Gümüşi havuz sazanı, marinasyon, kalite özellikleri, raf ömrü, sos

\section{INTRODUCTION}

Carassius gibelio (Bloch, 1782) (also known as the silver Prussian carp or gibel carp) is rapidly growing invader of freshwater ecosystems a cyprinid species native from Asia and then introduced in many other countries. The silver crucian carp Carassius gibelio is distributed mainly in the former Soviet Union, Europe, Korea and north-east China (Zou et al., 2000). Gibel carp was reported first by Baran and Ongan (1988) in Turkey. As well as most part of Europe, rapid increase in gibe carp and distribution in many parts of Turkey have reported
(Tarkan et al,. 2006). Although reported for 46 locations in Turkey, C. gibelio is likely to have a much wider distribution (Özcan, 2007).

Nowadays seafood processed and packaged in different ways to make ready for consumption food like in other food industries due to increasing demand for ready-to-eat products and developing technology (Özpolat et al., 2010).

Traditional seafood preservation methods are effective in 
controlling microbial activity but have adverse organoleptic and textural properties. The current demand for 'natural' foods, bring necessities of new approaches in seafood preservation (Siriskar et al., 2013).

Marination technique, based on BC 7th century, provides seasoning to fresh, frozen or salted fish or fish parts with vinegar and/or other organic acids and salt (Varlık, 1993a), without temperature effect. Marinades are semi-preserved product; produced by adding acetic acid and salt for of prevent from bacteria and enzymes for a while, which has its own taste and limited extended shelf life (Poligne and Collignan, 2000; Özden and Varlık, 2004; İnanlı et al,. 2010). At seasoning process, raw material become edible. For flavoring the marinade sugar, spices, sauce, cream, mayonnaise, vegetable oil and vegetables can be added and can be packed in glass bottle or plastic cap (İnanlı et al., 2010).

In this study, its aimed to assess the economic values of marinades from Carassius gibelio (Bloch 1782), an Asia originated omnivore fresh water species. C. gibelio moved to Europe with various routes and is used as feed for carnivore individuals or fish pricing at lakes, ponds and dams in our country. As it is not preferred by consumers with its heavy odour, taste and bony structure, marination with different sauces was evaluted for $\mathrm{C}$. gibelio contribution economically. The shelf life of gibel carp marinades in different sauces was investigated during storage at $4{ }^{\circ} \mathrm{C}$.

\section{MATERIAL AND METHODS}

\section{Sample Preperation and Marination Process}

Fresh gibel carp (Carassius gibelio, Bloch 1782) obtained from a local aquaculture farm in Karacasu near Aydın (Turkey). The samples (average weight $172 \pm 30.82 \mathrm{~g}$ and length $19.75 \pm 2$ $\mathrm{cm})$, placed in polystyrene foam boxes with flake ice and transferred to the Fish Processing Laboratory in Muğla Sıtk Koçman University Faculty of Fisheries within 2 hours. After arrival fish were decapitated and filleted by hand and washed under tap water. Fillets were dipped in an ice-water solution (1:4 (v/v) ice/water) for 60 min to provide physical cleaning and temperature stability.

The marinating process was performed in $2.5 \%$ acetic acid and $10 \%$ sodium chloride solution. Fish:solution ratio was $1: 1.5$ in each glass jar. Marinating was carried out at $4 \pm 1^{\circ} \mathrm{C}$ for $72 \mathrm{~h}$. When marinating process was completed, the fillets were removed from the solution and filtered and divided into three batches ( $4 \mathrm{~kg}$ each). The first batch (Control) was marinated by immersing the whole fillets in sunflower oil. The second batch (Group A) was marinated by immersing in $2500 \mathrm{~mL}$ sunflower oil with $110 \mathrm{~g}$ tomato paste and the third batch (Group B) was marinated by sunflower oil containing 6 garlic seed, $6 \mathrm{~g}$ red pepper, $2 \mathrm{~g}$ thyme, $2 \mathrm{~g}$ basil and $2 \mathrm{~g}$ mint. All batches were stored at $4 \pm 1^{\circ} \mathrm{C}$ for up to 135 days.

Throughout the storage period $(0,30,60,90,120,135$ days), sensory, chemical (proximate composition, $\mathrm{pH}$, total volatile basic nitrogen (TVB-N), thiobarbituric acid (TBA), free fatty acid (FFA), salt \% and acetic acid \%) and microbiological [total viable counts (TVC), psychrotrphic bacteria counts (PB) and total coliform counts (TCB)] analyses were performed.

\section{Sensory analyses}

Sensory properties of control group was also marinated so, all samples were evaluated by six experienced panellists from Muğla Sıtkı Koçman University and the results were evaluated as described by Sallam et al. (2007). Panellists gave scores for sensory characteristics appearance, colour, odor, texture, rancidity, juiciness, softness, acidity, saltiness, aftertaste and general acceptability. The overall acceptability of fish marinades were assessed on a scale of 1 to 9 ( 9 excellent, 8 very good, 7 good, 6 reasonable, 5 not good, 4 disliked, 3 bad, 2 very bad, 1 reject) (Sallam et al., 2007).

\section{Proximate analyses}

The fish samples were analysed in triplicate for proximate composition: lipid content by the Bligh and Dyer (1959) method, moisture and the ash by AOAC (1990) method, total crude protein by Kjeldhal method (AOAC 1984).

\section{Microbiological analyses}

The following groups of microflora were monitored: total viable count, psychrotrophic bacteria count and total coliform bacteria. A sample $(10 \mathrm{~g})$ was removed aseptically using a scalpel and forceps from the fillet, transferred to a stomacher bag containing $90 \mathrm{~mL}$ of sterile Peptone Water (PW) solution $(0.1 \%)$, and homogenized using a stomacher at room temperature. For each sample, further serial decimal dilutions were prepared in PW solution (0.1\%) (Gürgün and Halkman, 1988)

Total viable counts were determined using Plate Count Agar (PCA, Merck code 1.05463, Darmstadt, Germany) after incubation for 2 days $(24 \mathrm{~h}+24 \mathrm{~h})$ at $37^{\circ} \mathrm{C}$; psychrotrophic bacteria counts were determined after incubation at $7^{\circ} \mathrm{C}$ for 10 days with same medium (FDA/BAM, 2002). To count coliform bacteria, analysis was performed according to MPN method with $3 \times 3$ tubes. These tubes were left at $35^{\circ} \mathrm{C}, 48$ hours for incubation. Tubes were evaluated as positive if gas formation was observed (FDA/BAM, 2002).

\section{Chemical analyses}

The $\mathrm{pH}$ values were recorded by using a InoLab model digital $\mathrm{pH}$ meter (InoLab, WTW, Germany) after homogenization of each $10 \mathrm{~g}$ fish muscle in $100 \mathrm{ml}$ distilled water (Manthey et al., 1988). Total volatile basic nitrogen (TVBN) was determined according to Antonacopoulos and Vyncke (1989). Thiobarbituric acid (TBA) determined according to Tarladgis et al. (1960) to evaluate the oxidation stability during chilled storage. Free fatty acid (FFA) content, expressed as \% of oleic acid, was determined by acidometric titration of extracts 
after adding ethanol and using phenolphthalein as an indicator as following to AOCS (1998). Salt content determination was done according to Varlık et al. (1993a). Acidity was determined according to the method given by Karl (1994).

\section{Colour measurements}

The colour of samples was measured by a colorimeter (Pen Color Art 1L, Artoksi MSM, China) and was reported by the CIE system. $L^{*}, a^{*}$ and $b^{*}$ parameters indicate lightness/brightness, redness/greenness and yellowness/blueness, respectively. The colourimeter was calibrated with a white standard.

\section{Statistical analysis}

Experiments were performed in triplicate $(n=3)$ and a completely randomised design (CRD) was used. Analysis of variance (ANOVA) was performed and the mean comparisons were done by Duncan's multiple range tests. Statistical analysis was performed using the Statistical Package for Social Sciences (SPSS for Windows, SPSS Inc., Chicago, IL, USA).

\section{RESULTS AND DISCUSSION}

\section{Sensory analysis results}

Results of sensory analysis of all groups were shown in Table 1. The most important fact which influences preference of consumers is sensory characteristics (Huss, 1995). In our research marinated gibel carp which were prepared as control, group $A$ and $B$ were presented to panelists in all stages of analysis. Group B maintained its quality until 135th day according to the panelists. Group A and control were seen to reach unacceptable limits after 105th and 120th days respectively. In terms of general acceptance; group B were appreciated more than control and group $A$ marinades $(P<0,05)$. Because the spices used in group $B$ was thought to have a positive effect on the flavor and appearance.

Table 1. Results of sensory evaluation of marinades in different sauces

\begin{tabular}{|c|c|c|c|c|c|c|}
\hline & \multicolumn{6}{|c|}{ Storage Time (Days) } \\
\hline & 0 & 30 & 60 & 90 & 120 & 135 \\
\hline Control & $8.76 \pm 2.34^{\mathrm{aA}}$ & $8.30 \pm 0.26 \mathrm{aA}$ & $7.30 \pm 0.53^{\mathrm{bA}}$ & $6.93 \pm 1.10^{\mathrm{bA}}$ & $5.65 \pm 0.72^{\mathrm{cA}}$ & $4.57 \pm 0.38^{\mathrm{d} A}$ \\
\hline \multicolumn{7}{|l|}{ General accept } \\
\hline Group A & $8.76 \pm 2.34^{\mathrm{aA}}$ & $8.20 \pm 0.67^{\mathrm{aA}}$ & $7.47 \pm 0.67^{\mathrm{bA}}$ & $6.50 \pm 1.56^{\mathrm{cA}}$ & $4.93 \pm 1.11 \mathrm{~dB}$ & $3.90 \pm 0.69 \mathrm{eB}$ \\
\hline Group B & $8.76 \pm 2.34 \mathrm{aA}$ & $8.55 \pm 0.17 \mathrm{aA}$ & $8.23 \pm 0.74^{\mathrm{aB}}$ & $7.35 \pm 0.93^{\mathrm{bB}}$ & $6.87 \pm 0.85^{c c}$ & $6.10 \pm 0.52^{\mathrm{cc}}$ \\
\hline
\end{tabular}

Lowercase letters used exponentially in the same column show statistical difference between days while capital letters used exponentially in the same line show groups. $(P<0.05)($ Mean \pm STD)

\section{Microbiological analysis results}

Analysis results of total viable count (TVC), psychrotrophic bacteria (PB) and total coliform bacteria (TCB) were shown in Table 2. The initial TVC, PB and TCB counts of flesh gibel carp determined as 4.1, 3.4 CFU / $g$ and $8.0 \mathrm{MPN} / \mathrm{g}$ respectively. At the end of storage, TVC counts for control, group A and group $B$ respectively were determined as $5.4,5.6$ and $3.9 \mathrm{CFU}$ $\mathrm{g}$, PB counts were determined as 2.8, 3.0 and $2.0 \mathrm{CFU} / \mathrm{g}$. TCB counts of all groups at the end of storage were determined as $<3 \mathrm{MPN} / \mathrm{g}$. Generally, microbial flora of fish varies due to fish species, season, nutritional conditions, developmental stage of the fish and the type of water it exists (Sen and Temelli, 2003).

It was seen that microbiological load decreased in acedic acid and salt treated samples during storage $(P<0.05)$. Indeed it is thought that spices which were used in group $B$ showed antimicrobial effect. It was reported that garlic has a maximum antimicrobial effect against spoilage bacteria which causes food poisoning (Can et al., 2011). Increasing was determined partially for TVC and PB towards the end of the storage $(P<0.05)$. Wenjiao et al. $(2013)$ reported that the initial number of bacteria in the silver carp muscle was $3.0 \log 10 \mathrm{CFU} / \mathrm{g}$, which indicated a good quality of the fish used in this experiment. Sallam et al. (2007) was determined chemical and sensory characteristics of pacific saury (Cololabis saira) which was marinated in $\% 12$ salinity, $\% 3$ and $\% 2$ acetic acid and psychrotrophic bacteria count was $3.95 \log 10$ CFU / g at the beginning, however an important decrease was observed after marination process $(p<0.05)$ and regress respectively to 1.55 and $1.7 \log 10$ CFU / g. Çolakoğlu (2004), was reported microbial count of last products which have obtained with different processing techniques, decreases significantly in comparison with fresh fish fillets and especially was put forth that the minimum bacteria content is at marinades technology. Sen and Temelli (2003) reported that the vegetable additives and sauces used after marination did not affect on hygienic quality of the end product since they were also marinated. 
Table 2. Microbiological analysis results of marinades in stored different sauced

\begin{tabular}{|c|c|c|c|c|c|c|c|c|}
\hline & \multirow[b]{2}{*}{ Groups } & \multicolumn{7}{|c|}{ Storage Time } \\
\hline & & Raw material & 0 & 30 & 60 & 90 & 120 & 135 \\
\hline \multirow{3}{*}{ TVC (CFU/g) } & Control & $4.1 \pm 0.04$ & $2.1 \pm 0.14$ & $2.0 \pm 0.08$ & $2.6 \pm 0.06$ & $4.4 \pm 0.02$ & $5.1 \pm 0.13$ & $5.4 \pm 0.04$ \\
\hline & Group A & $4.1 \pm 0.04$ & $2.1 \pm 0.14$ & $2.0 \pm 0.12$ & $3.4 \pm 0.10$ & $4.0 \pm 0.03$ & $5.2 \pm 0.08$ & $5.6 \pm 0.21$ \\
\hline & Group B & $4.1 \pm 0.04$ & $2.1 \pm 0.14$ & $2.3 \pm 0.18$ & $3.2 \pm 0.03$ & $4.3 \pm 0.08$ & $4.0 \pm 0.14$ & $3.9 \pm 0.12$ \\
\hline \multirow{3}{*}{ PB (CFU/g) } & Control & $3.4 \pm 0.03$ & $<\log 10$ & $<\log 10$ & $<\log 10$ & $<\log 10$ & $<\log 10$ & $2.8 \pm 0.12$ \\
\hline & Group A & $3.4 \pm 0.03$ & $<\log 10$ & $2.0 \pm 0.11$ & $2.0 \pm 0.05$ & $<\log 10$ & $<\log 10$ & $3.0 \pm 0.06$ \\
\hline & Group B & $3.4 \pm 0.03$ & $<\log 10$ & $<\log 10$ & $<\log 10$ & $<\log 10$ & $<\log 10$ & $2.0 \pm 0.09$ \\
\hline \multirow{3}{*}{$\begin{array}{c}\text { TCB } \\
\text { (MPN/g) }\end{array}$} & Control & $8,0 \pm 0.11$ & $7,2 \pm 0.08$ & $<3$ & $<3$ & $<3$ & $<3$ & $<3$ \\
\hline & Group A & $8,0 \pm 0.11$ & $7,2 \pm 0.10$ & $<3$ & $<3$ & $<3$ & $<3$ & $<3$ \\
\hline & Group B & $8,0 \pm 0.11$ & $7,2 \pm 0.03$ & $<3$ & $<3$ & $<3$ & $<3$ & $<3$ \\
\hline
\end{tabular}

(Mean \pm STD, n:3) TVC: total viable count, PB: psychrotrophic bacteria, TCB: total coliform bacteria, MPN/g: Most probable number in a gram, $\mathrm{CFU} / \mathrm{g}$ : coloni form units in a gram

\section{Proximate composition analysis results}

$\%$ crude protein, crude lipit, moisture, crude ash values of raw material and marinated fish were shown in Table 3. \% crude protein, crude lipit, moisture, crude ash values of raw material in our study were determined as $16.75,1.13,80.14$ and 0.87 respectively. Cui et al., (2006) have reported that gibel carp has $78.2 \%$ moisture, $14.2 \%$ protein, $3.0 \%$ lipid and $3.4 \%$ ash content. A rapid decrease was seen at $\%$ moisture value until 30th day and it remained stable with decrease partially $(P<0.05)$ towards the end of the storage.
The reason of this decrease is osmosis. The ionic strength of the muscle tissue fluid is lower than that of brine, and through the process of osmosis, the brine solution will be absorbed by the meat until a state of equilibrium is reached (Alvarado and McKee, 2007). The highest moisture loss occured at group B. Cabrer et al. (2002) was reported marinated anchovy fillets have $\% 72.01 \pm 0.27$ moisture ratio, $\% 19.13 \pm 0.98$ crude protein, $\% 4.58 \pm 0.49$ crude lipid, $\% 5.35 \pm 0.09$ crude ash and marination process decreased moisture ratio, increased protein, lipid and ash ratios.

Table 3. Proximate analysis results of raw material and after marination

\begin{tabular}{llccccc}
\hline & Groups & $\begin{array}{c}\text { Protein } \\
(\%)\end{array}$ & $\begin{array}{c}\text { Lipid } \\
(\%)\end{array}$ & $\begin{array}{c}\text { Moisture } \\
(\%)\end{array}$ & $\begin{array}{c}\text { Ash } \\
(\%)\end{array}$ & $\begin{array}{c}\text { Carbonhdyr } \\
\text { ate }(\%)\end{array}$ \\
\hline Raw Material & & $16.75 \pm 0.27^{\mathrm{a}}$ & $1.13 \pm 0.11^{\mathrm{a}}$ & $80.14 \pm 0.55^{\mathrm{a}}$ & $0.87 \pm 0.16^{\mathrm{d}}$ & $1.11 \pm 0.03^{\mathrm{c}}$ \\
After maturation & & $16.95 \pm 0.21^{\mathrm{a}}$ & $1.30 \pm 0.04^{\mathrm{a}}$ & $78.34 \pm 0.34^{\mathrm{b}}$ & $1.96 \pm 0.22^{\mathrm{c}}$ & $1.45 \pm 0.17^{\mathrm{b}}$ \\
& Control & $17.01 \pm 0.62^{\mathrm{a}}$ & $3.8 \pm 0.04^{\mathrm{c}}$ & $72.41 \pm 0.15^{\mathrm{c}}$ & $5.35 \pm 0.64^{\mathrm{b}}$ & $1.44 \pm 0.11^{\mathrm{b}}$ \\
At the end of storage & Group A & $16.69 \pm 0.17^{\mathrm{a}}$ & $5.07 \pm 0.59^{\mathrm{a}}$ & $70.86 \pm 0.70^{\mathrm{d}}$ & $6.12 \pm 1.13^{\mathrm{a}}$ & $1.26 \pm 0.09^{\mathrm{bc}}$ \\
period & Group B & $16.88 \pm 0.12^{\mathrm{a}}$ & $4.22 \pm 0.15^{\mathrm{b}}$ & $70.53 \pm 0.06^{\mathrm{d}}$ & $5.97 \pm 0.25^{\mathrm{a}}$ & $2.39 \pm 0.18^{\mathrm{a}}$ \\
\hline
\end{tabular}

Between the groups shown with different letters are significantly different $(p<0.05)$ (Mean \pm STD, $n: 3)$

\section{Chemical Analysis Results}

$\mathrm{pH}$ value is an important fact that influences microbial and enzymatic variations. During marination, $\mathrm{pH}$ value of fresh fish decreases significantly (İnanlı et al., 2010). pH value of gibel carp was determined as 6.54 before marination while marinated fish of $\mathrm{pH}$ value was 4.34 (Figure 1). A few increase was seen at all groups during storage $(P>0.05)$.
In comparison with other groups $\mathrm{pH}$ value of group $\mathrm{B}$ was lower at the end of the storage. Proteins are denaturated and $\mathrm{pH}$ value decreases by diffusing of salt and acetic acid in fish meat during marination process (Karl et al., 1995). Olgunoğlu (2007) invastigated sensory, chemical and microbiological variations of anchovy marinades in their study and $\mathrm{pH}$ value was 6.21 in raw material while this value changes between 3.89-4.27 in marinades during storage. Poligne and Colignan 
(2000) found that the $\mathrm{pH}$ levels of anchovies pickled with acetic acid increased from 3.90 to 4.21 after 20 days of storage and then remained constant until the end of the storage.

TVB-N analysis results were shown in Figure 2. The initial TVB-N value of the raw material was $11.98 \mathrm{mg} / 100 \mathrm{~g}$. After marination process the value determined as $7.67 \mathrm{mg} / 100 \mathrm{~g}$. TVB-N values showed increase consistently at the end of the storage $(P<0.05)$. TVB-N value of all groups until storage of 135 days did not exceed unacceptable limit of $32-36 \mathrm{mg} / 100 \mathrm{~g}$ and it was determined that it takes a place in consumable product class (Varlık et al., 2004). It was determined that quality of group B were better in comparison with other groups, group A reached low quality values towards at the end of the storage. This condition is thought especially because of protection effect of spices that exist in group $B$.

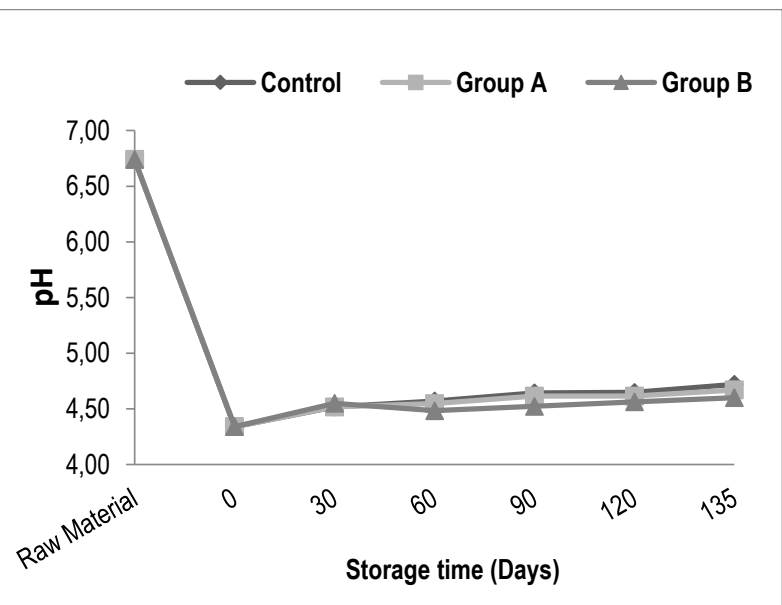

Figure 1. pH analysis results of marinades stored in different sauces

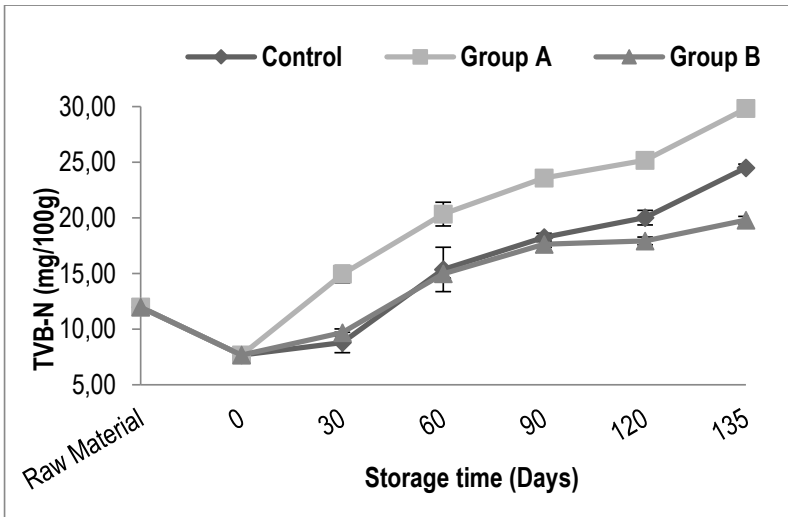

Figure 2. TVB-N analysis results of marinades stored in different sauces

TBA analysis results of samples were shown in Figure 3. TBA is widely used as an indicator of the degree of lipid oxidation, which can lead to off-flavour, colour and odour changes, and contribute to the texture deterioration in the fish products (Wenjiao et al. 2013). It was reported TBA has to be below 3 in good material and consumability limit is between 78 (Varlık et al., 1993b). The initial TBA value of the raw material was $0.36 \mathrm{mg}$ malonaldehyde / $\mathrm{kg}$. This value increased during storage for all groups however did not exceed limit. The lowest TBA values were seen at group B samples, group A samples reached low quality values. In particular spices such as oregano, mint, basil, garlic in group $B$ showed antioxidant features. So, TBA values that index of oxidation remained low level for group B. The initial TBA values in sardine marinades were $4.47 \mathrm{mg}$ malonaldehyde/kg and changes up to $8.21 \mathrm{mg}$ malonaldehyde/kg during storage (Kılınç and Çaklı, 2005).

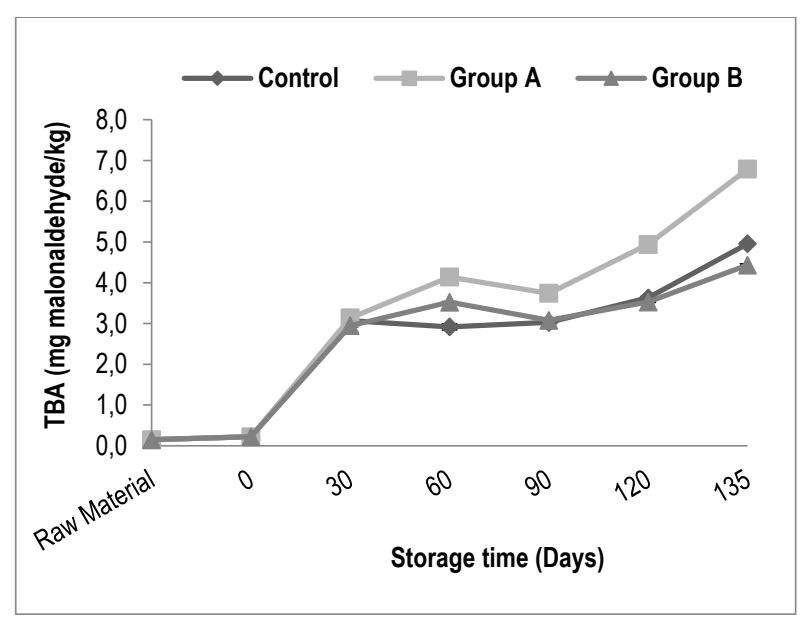

Figure 3. TBA analysis results of marinades stored in different sauces

Free fatty acid (FFA) analysis results were shown in Figure 4. The initial FFA value of raw material was 0.15 oleic acid \%. This value increased significantly during storage time $(P<0.05)$. At the end of storage, this value for control, group $A$ and group $B$ were determined as 4.32, 3.67 and 2.01 oleic acid \%, respectively.

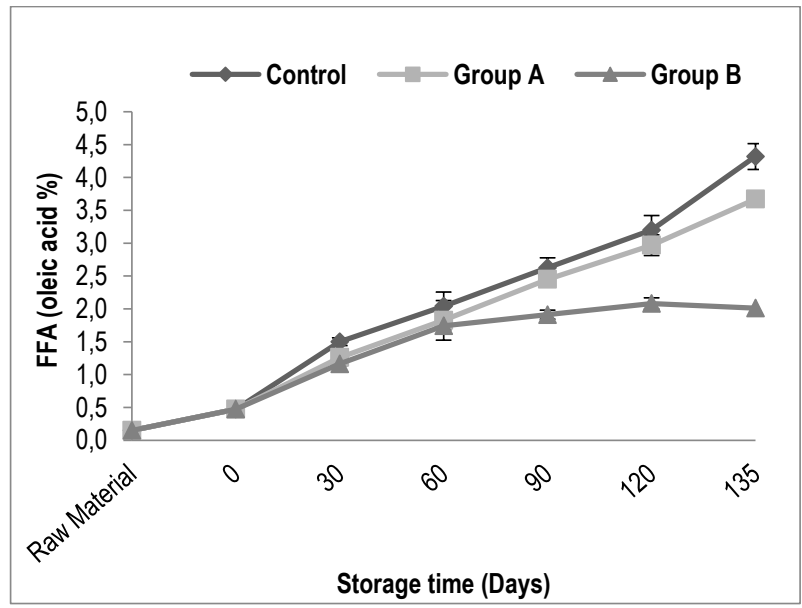

Figure 4. FFA analysis results of marinades stored in different sauces 
Variation of salt content in samples during storage was shown in Figure 5. Salt that used in marination process acquires hardness besides flavour to fish meat (Varlık et al., 1993a). \% salt content of control group increased $(P<0.05)$ consistently until the end of the storage. This situation was also mentioned by panelists. There was no change on salt content after 30th day in group A and B marinades. The lowest salt content was determined in group $B$ marinades. It was thought that ingredients used in group $A$ and $B$ marinades inhibited transition of salt to meat. In terms of sensory quality, salt content of group B marinades appreciated by panelists comparison with other groups supports this result.

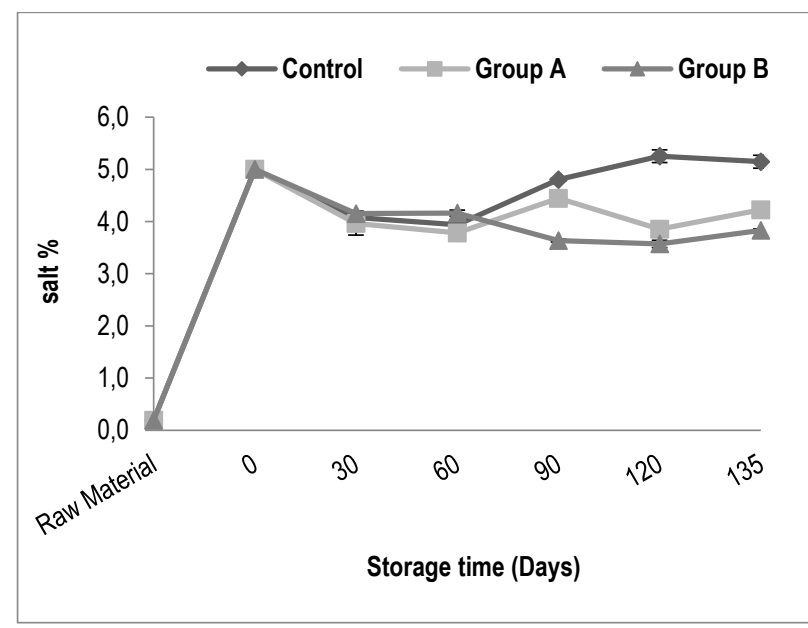

Figure 5. \% Salt analysis results of marinades stored in different sauces

Acetic acid contents were shown in Figure 6. Acetic acid is effective at destruction of amino acids which is an aromatic transporter of proteinaceous material (Çoban ve Özpolat, 2011). In control and group A marinades an increase was observed consistently until the end of the storage $(P<0.05)$. The lowest acetic acid content was determined at group $B$ marinades. Acetic acid content of all three groups was liked by sensory panelists and the content was determined ideal for fish meat.

While an increased (brightness) occured in $L^{*}$ value of control and group $B$ marinades $(P<0.05)$, there were not much change of group A marinades. Tomato paste, used in group $A$ marinades, effects the brightness of meat. There were not much change was observed in terms of $a^{*}$ value of control and group $B$ marinades $(P>0.05)$. After putting the meat within sauce, an increase observed in $a^{*}$ value in group $A$ marinades
$(P<0.05)$ however this value decreased increasingly through the end of storage. It has been seen that the $a^{*}$ value affected by mostly tomato paste. An increase towards to positive in $b^{*}$ value is an indication of yellowness. When results were evaluated in terms of $b^{*}$ all marinades show an increase $(P<0.05)$. At the end of storage while redness was decreasing yellowness reached highest point in group $A$ marinades.

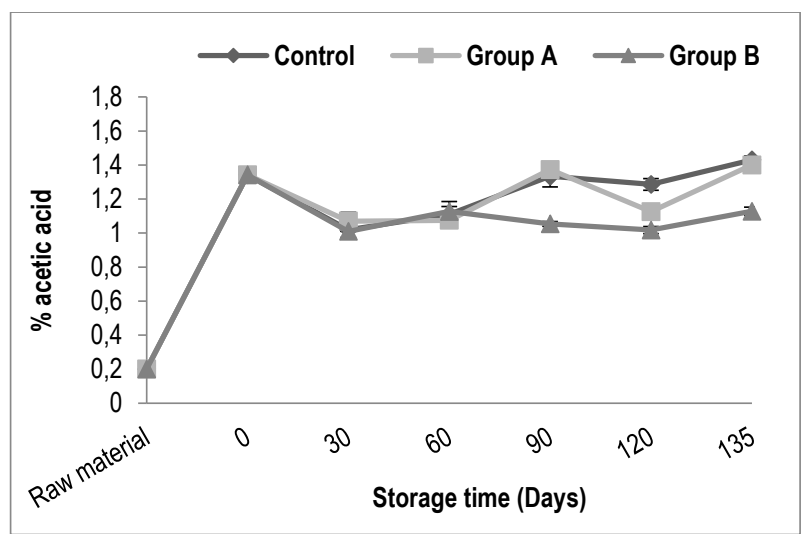

Figure 6. \% Acetic acid analysis results of marinades stored in different sauce

\section{CONCLUSIONS}

In this study sensory, chemical and microbiological quality of gibel carp (Carassius gibelio), marinades in different sauces, were determined and evaluated. Consequently in terms of sensory analysis samples of Control, group $A$ and group $B$ were found to retain the property of acceptable at $120^{\text {th }}, 105^{\text {th }}$ and $135^{\text {th }}$ day respectively. When study results considered overall; gibel carp, is an invasive species and has no economical value, can utilized with marinate. This species could serve up to consumers as ready to eat food in different sauced thus expanding range of products can contribute to the national economy. Acetic acid used in marinade process is effective upon tiny bones nevertheless it may not be effective in large bones. That's why we suggest to use $2 \%$ acetic acid with small fish while $2-3 \%$ with bigger fishes in gibel carp marinade.

\section{ACKNOWLEDGEMENTS}

The authors appreciate the financial support of Mugla Sitki Kocman University Scientific Research Projects Coordination Unit (No. 12/02).

\section{REFERENCES}

Antonacopoulos, N., \& Vyncke, W. (1989). Determination of volatile basic nitrogen in fish: a third collaborative study by West European Fish Technologists' Association (WEFTA). Zeitschrift für LebensmittelUntersuchung und -Forschung A, 189: 309-316. doi: 10.1007/BF01683206

Alvarado, C., \& McKee, S. (2007). Marination to improve functional properties and safety of poultry meat. The Journal of Applied Poultry Research, 16 (1): 113-120. doi: 10.1093/japr/16.1.113

AOAC (1984). Official methods of analysis of the Association of Official Analytical Chemists. $14^{\text {th }}$ ed. Washington, DC. 
AOAC (1990). Official methods of analysis of the Association of Official Analytical Chemists. 2 vols. $15^{\text {th }}$ ed. Washington, DC

AOCS (1998). In Official Methods and Recommended Practices of the American Oil Chemists' Society; $5^{\text {th }}$ Edition, Champaign, IL.

Baran, I., \& Ongan, T. (1988). Limnological characteristics of Gala lake, fishing issues and recommendations. Gala Gölü ve Sorunları Sempozyumu, Doğal Hayatı Koruma Derneği Bilimsel Yayınlar Serisi, 46-54.

Bligh, E.G., \& Dyer, W.J. (1959). A rapid method of total lipid extraction and purification. Canadian Journal of Biochemistry and Physiology, 37: 911 917. doi: 10.1139/059-099

Cabrer, A.I., Casales, M.R., \& Yeannes, M.I. (2002). Physical and chemica changes in anchovy (Engraulis anchoita) flesh during marination. Journal of Aquatic Food Product Technology, 11(1): 19-31. doi:10.1300/J030v11n01_03

Can, P.Ö., Yalçın, H., \& Arslan, A. (2011). Assessment of quality criteria of Cyprinus carpio fillets marinated with eugenole solution for different time (in Turkish with English abstract). The Black Sea Journal of Science, 2(5): 17-27.

Coban, Ö.E., \& Özpolat, E. (2011). Assessment with various sauces of marinated red Mullet (Mullus barbatus barbatus L., 1758) by differen acetic acids solutions (in Turkish with English abstract). SDU Journal of Science (E-Journal), 6(1): 26-34.

Colakoğlu, F.A., (2004). The Effects of processing techniques on microflora of roach (Rutilus rutilus) and whitefish (Coregenus sp). Turkish Journal of Veterinary and Animal Sciences, 28: 239-247. doi: 10.3923/pjbs.2007.3002.3005

Cui, Z.H., Wang, Y., \& Qin, J.G. (2006). Compensatory growth of group-held gibel carp, Carassius auratus gibelio (Bloch), following feed deprivation. Aquaculture Research, 37(3): 313-318.

FDA/BAM (2002). Food and drug analyses/bacteriological analytical manual, Aerobic plate count. Edition 8, Chapter 3, January.

Gürgün, V., \& Halkman, K.T. (1990). Mikrobiyolojide sayım yöntemleri. Gıda Teknolojisi Derneği, Yayın No:7, San Basım, Ankara.

Huss, H.H. (1995). Quality and Quality Changes in Fresh Fish. Technical paper: 348, Rome: Food and Agriculture Organization (FAO) of the United Nations 132

İnanlı, A.G., Özpolat, E., Çoban, E.O., \& Karaton, N. (2010). Chemica composition of marinated anchovy (Engraulis encrasicolus L., 1758) and sensory evaluation in different sauce (in Turkish with English abstract). Journal of FisheriesSciences.com, 4(4): 455-461. doi: 10.3153/jfscom.2010049

Karl, H. (1994). Überlegungen zur berechnung der salz-und sauregehalte im fischgewebewasser von marinierten fischereierzeugnissen. Fischwirtschaft, 41(1): 47-59. doi: 10.1007/s13197-011-0597-4

Karl, H., Roepstorf, A., Huss, H.H., \& Bloemsma, B. (1995). Survival of Anisakis larvae in marinated herring fillets. International Journal of Food Science \& Technology, 29: 661-670. doi: 10.1111/j.1365-2621.1994.tb02107.x

Kılınç, B., \& Çaklı, S. (2005). Determination of the shelf-life of sardine (Sardina pilchardus) marinades in tomato sauce stored at $4{ }^{\circ} \mathrm{C}$. Food Control, 16 : 639-644. doi: 10.1016/j.foodcont.2004.07.004

Manthey, M., Karnop, G., \& Rehbein, H. (1988). Quality changes of European catfish from warm-water aquaculture during storage ice. International Journal of Food Science \& Technology, 23: 1-9. doi: 10.1111/j.1365-2621.1988.tb00543.x
Olgunoğlu, İ.A. (2007). Sensory, chemical and microbiological changes of marinated anchovies (Engraulis encrasicolus L. 1758), (in Turkish), PhD thesis, Cukurova University, Institute of Science and Technology, Adana

Özcan G. (2007). Distribution of non-indigenous fish species, Prussian carp Carassius gibelio (Bloch, 1782) in the Turkish freshwater systems. Pakistan Journal of Biological Sciences, 10: 4241-4245. doi: 10.3923/pjbs.2007.4241.4245

Özden, O., \& Varlık, C. (2004). Marinat Teknolojisi. In: C. Varlık (Ed.) Su Ürünleri Işleme Teknolojisi, İstanbul Üniversitesi, (s. 205-230), İstanbul.

Özpolat, E., Çoban, Ö.E., \& Patır, B. (2010). The sensory features of rainbow trout (Oncorhynchus mykiss) marinades prepared in different acetic acid and eugenol ratios. Journal of FisheriesSciences.com, 4(4): 329-336. doi: $10.3153 /$ jfscom. 2010036

Poligne, I., \& Collignan, A. (2000). Quick marination of anchovies (Engraulis enchrasicolus) using acetic and gluconic acids. Quality and stability of the product. Lebensmittel Wissenschaft und Technology, 33: 202-209. doi: $10.1006 /$ fstl.2000.0635

Sallam, K.H.I., Ahmed, A.M., Elgazzar, M.M., \& Eldaly, E.A. (2007). Chemical quality and sensory attributes of marinated pacific saury (Cololabis saira) during vacuum-packaged storage at $4{ }^{\circ} \mathrm{C}$. Food Chemistry, 102(4): 1061 1070. doi: 10.1016/j.foodchem.2006.06.044

Sen, M.K.C., \& Temelli, S. (2003). Microbiological and chemical qualities of marinated anchovy prepared with different vegetable additives and sauce. Revue de Medicine Veterinaire, 154: 703-707.

Siriskar, D.A., Khedkar, G.D., \& Lior, D. (2013). Production of salted and pressed anchovies (Stolephorus sp.) and it's quality evaluation during storage, The Journal of Food Science and Technology, 50(6): 1172-1178. doi: 10.1007/s13197-011-0450-9

Tarkan, A.S., Gaygusuz, Ö., Gürsoy, Ç., Acıpınar, H., \& Bilge, G. (2006). A new predator species Carassius gibelio (Bloch, 1782) in Marmara Region: successful or not. 1. Balıklandırma ve Rezervuar Yönetimi Sempozyumu, Antalya.

Tarladgis, B.G., Watts, B.M., \& Younathan, M.T.A. (1960). A distillation method for the quantitative determination of malonaldehyde in rancid foods. Journal of the American Oil Chemists' Society, 37: 44-48. doi: $10.1007 / B F 02630824$

Varlık, C., Erkan, N., Özden, Ö., Mol, S., \& Baygar, T. (2004). Su ürünleri işleme teknolojisi İstanbul Üniversitesi Basım Yayınevi, Istanbul.

Varlık, C., Uğur, M,, Gökoğlu, N., \& Gün, H. (1993a). The effect of temperature on the penetration of vinegar/salt (in Turkish with English abstract). Gida, 18(4): 223-228.

Varlık, C., Uğur, M., Gökoğlu, N., \& Gün, H. (1993b). Su ürünlerinde kalite kontrol ilke ve yöntemleri. Gıda Teknolojisi Derneği, 17: 174

Zou, Z., Cui, Y., Gui, J., \& Yang, Y. (2000). Growth and feeding utilisation in two strains of gibel carp, Carassius auratus gibelio: paternal effects in a gynogenetic fish. Journal of Applied Ichthyology, 17: 54-58. doi: 10.1046/j.1439-0426.2001.00245.x

Wenjiao, F., Yongkui, Z., Pan, D., \& Yuwen, Y. (2013). Effects of chitosan coating containing antioxidant of bamboo leaves on qualitative properties and shelf life of silver carp during chilled storage. Czech Journal of Food Sciences, 31: 451-456. 